\title{
Reach scale ecologic influence of in-stream large wood in a Coastal Mountain range channel, Southern Chile
}

\section{Influencia ecológica a nivel de tramo de la madera en el cauce en un canal de la Cordillera de la Costa, sur de Chile}

\author{
Macarena Vera ${ }^{1}$, Carlos Jara ${ }^{2}$, Andrés Iroumé ${ }^{3}$, Héctor Ulloa ${ }^{4}$, Andrea Andreoli ${ }^{5,6}$ \& Sebastián \\ BARRIENTOS ${ }^{7}$
}

${ }^{1}$ Universidad Austral de Chile, Faculty of Forest Sciences and Natural Resources, School of Engineering in Natural Resources Conservation, Independencia 631, Valdivia 5110566, Chile. (macarenavera.so@gmail.com)

2 Universidad Austral de Chile, Faculty of Sciences, Independencia 631, Valdivia 5110566, Chile. (cjara@uach.cl)

${ }^{3}$ Universidad Austral de Chile, Faculty of Forest Sciences and Natural Resources, Independencia 631, Valdivia 5110566, Chile. (airoume@uach.cl)

${ }^{4}$ Universidad Austral de Chile, Faculty of Forest Sciences and Natural Resources, Graduate School, Independencia 631, Valdivia 5110566, Chile. (ulloacontreras@gmail.com)

${ }^{5}$ Universidad de Concepción, Department of Forestry and Environmental Management, Víctoria 631, Concepción 4030000, Chile. (aandreoli@udec.cl)

${ }^{6}$ Free University of Bozen-Bolzano, Faculty of Science and Technology, Bolzano, Italy.

7 Universidad Austral de Chile, Faculty of Engineering, School of Civil Engineering, Independencia 631, Valdivia 5110566,

Chile. (seba.abm@gmail.com)

* Corresponding author

\begin{abstract}
The ecologic influence of in-stream large wood (LW) was evaluated at reach scale in a third-order channel located in the Coastal Mountain Range, southern Chile. The tested hypotheses were that Coarse Particle Organic Matter (CPOM) retention is higher and benthic macro-invertebrates are more diverse in channel reaches storing higher volumes of LW. Three LW-low-volume reaches (mean LW volume of $8 \mathrm{~m}^{3} 100 \mathrm{~m}^{-1}$ of reach channel length; plane bed morphology) and three LW-high-volume reaches (mean volume $262 \mathrm{~m}^{3} 100 \mathrm{~m}^{-1}$; forced pool riffle bed morphology) were selected within a $1557 \mathrm{~m}$-long segment of the study channel. CPOM retention was inferred from the difference between the number of leaves collected in the downstream end of each reach and the leaves introduced in the upstream end. Mean CPOM retention was 72 and $90 \%$ among LW-low and high volume reaches, and showed a positive correlation $(R=0.61)$ with LW volume. Macro-invertebrates were more diverse and abundant in LW-high-volume reaches and the richness was twice than in LW-low-volume reaches. Bray-Curtis similarity index was low (40\%) between LW-high and low volume reaches, while it was high $(>60 \%)$ among LW-low-volume reaches. Results confirm the hypothesis that OM retention and benthic macro-invertebrate diversity and abundance were higher in high LW volume reaches. The higher diversity and abundance of macro-invertebrates associated with LW accumulations confirm that logjams constitute a biotope that offers shelter and food. These results can guide the assessment of environmental impacts of stream intervention and restoration projects. The study was undertaken within the framework of Project Fondecyt 1110609.
\end{abstract}

KEYwORDS: Organic matter retention; Macro-invertebrates; Large wood; Mountain river; Chile

\section{RESUMEN}

La influencia ecológica de la madera en el cauce (LW) fue evaluada a nivel de tramo en un canal de tercer orden localizado en la Cordillera de La Costa, sur de Chile. Las hipótesis planteadas fueron que la retención de Materia Orgánica Particulada Gruesa (CPOM) es mayor y que la diversidad de macro-invertebrados bentónicos es también mayor en tramos que almacenan una mayor cantidad de LW. Tres tramos con bajo volumen de LW (volumen medio de $8 \mathrm{~m}^{3} 100 \mathrm{~m}^{-1}$ de largo de tramo; morfología de lecho plano) y tres tramos con alto volumen de LW (volumen medio de $262 \mathrm{~m}^{3} 100 \mathrm{~m}^{-1}$; morfología de lecho de rápidos y pozas) se seleccionaron dentro de un segmento de $1557 \mathrm{~m}$ de largo en el canal estudiado. La retención de CPOM fue inferida de la diferencia entre el número de hojas recogidas al final de cada tramo y las hojas introducidas al canal en el extremo de aguas arriba. La retención promedio de CPOM fue 72 y $90 \%$ en tramos con bajo y alto volumen 
de LW, y mostró una correlación positiva $(R=0,61)$ con el volumen de LW. La diversidad y abundancia de macroinvertebrados fuero mayor en tramos con mayor volumen de LW y la riqueza fue el doble que en tramos con bajo volumen de LW. El índice de similaridad de Bray-Curtis fue bajo (40\%) entre tramos con alto y bajo volumen de LW, mientras que fue alto $(>60 \%)$ entre tramos con bajo volumen de LW. Los resultados confirman la hipótesis que la retención de CPOM y la diversidad y abundancia de macro-invertebrados bentónicos fueron mayores en tramos con mayor volumen de LW. La mayor diversidad y abundancia de macro-invertebrados asociadas con acumulaciones de LW confirman que los diques de madera constituyen un biotopo que ofrece protección y alimento. Estos resultados pueden guiar la evaluación de los impactos ambientales de proyectos de intervención o restauración de cauces. Este estudio fue desarrollado en el marco del Proyecto Fondecyt 1110609.

Palabras claves: Retención de materia orgánica; Macro-invertebrados; Material leñoso de gran tamaño; Río de montaña; Chile

\section{INTRODUCTION}

In the forested landscapes of the Pacific coastal eco-region of North America one of the most obvious indications of the physical, chemical, and biologic connection between riverine and terrestrial ecosystems is the great abundance of in-stream large wood (LW) deposited in the river channels (Bilby \& Bisson 1998).

Geomorphology, hydraulic processes, riparian vegetation, and aquatic biota, are functionally linked by CPOM retention processes (Gregory et al. 1991). Retention characteristics of the stream channel are closely related to the structure and composition of the adjacent riparian zones, which provide most of the large wood material, critical for the CPOM retention (Raikow et al. 1995). Changes in the vegetation cover and land uses of a basin affect the physical and chemical characteristics of streams, and consequently the aquatic life. Some consequences of landscape disruptions on the fluvial environment are changes of nutrient mobility, light, temperature, fine sediments load and periphyton abundance patterns, which affect the aquatic invertebrates by decreasing water clearness and the quality of suitable stream habitats (Death et al. 2003). These are the reasons why ecological restoration projects of rivers and basins have focused on increasing the habitat complexity and favoring the organic matter retention, by introducing wood elements into the channel in order to enhance sedimentation and to increase macro-invertebrate biodiversity (Castro \& Melo 2008; Entrekin 2008; Muotka \& Laasonen 2002; Negishi \& Richardson 2003). Reports in North America and Great Britain also emphasize that LW accumulations affect the hydraulic behavior, and the sediments transport and storage processes, conditioning the types and forms of sediment distribution on the channel bottom. Those effects depend on the channel morphology, large wood recruitment processes, and dimensions of the wood pieces in the river system (Bilby \& Ward 1989; Gurnell \& Sweet 1998; Keller \& Swanson 1979; Swanson \& Lienkaemper 1984). Furthermore, wood is the element with higher roughness that can be found in the channel and influences the morphology of the channel by decreasing the average water velocity within a certain reach and trapping fluvially transported organic material (Hauer \& Lamberti 2007).

Although different reports provide information about the effects of LW accumulations on the morphology and hydraulics of some Chilean mountain channels, their implications on the biological processes have not been described nor interpreted in Chilean lotic systems. Andreoli et al. (2007) and Comiti et al. (2008) described that in a stream of the Andes Range LW dams dissipate potential energy and increase flow resistance by up to one order of magnitude compared with the flow in absence of LW dams. Iroumé et al. $(2010,2011)$ and Ulloa et al. (2011) mentioned that the abundance and distribution of in-stream LW accumulations play a key role in trapping sediments and LW mobilization was higher during high floods exceeding bankfull stage.

The native evergreen forests of the Coastal Mountain range in Chile, characterized by a high proportion of endemic species and a very singular biodiversity, has been reduced to the $30 \%$ of their original extension during the last decades (Bello et al. 2003). It is important to increase the knowledge about the ecohydrologic relation between riparian forests and rivers in these unique environments to better understand the biological processes supporting the survival of habitats and communities. From that functional linkage two hypotheses are derived, i.e., that accumulation of wood elements within the channel increases the retention capacity of sediments eroded from the catchment area, and that the retention of coarse particulate organic matter by LW accumulations determines a higher reserve of CPOM that benefits the diversity and abundance of benthic macro-invertebrates. The evaluation of both hypotheses and their subsequent integration will contribute to a better understanding of the dynamic of coarse leaf material degradation produced by native, multispecies, uneven-aged forest cover, particularly in small lotic systems such as the Vuelta de Zorra stream, 
in the Valdivian Coastal Reserve, Southern Chile. This study evaluated the CPOM (floating leaves) retention capacity derived by the presence of in-channel LW, either as individual elements or accumulations. The overall objective of this study was to determinate the influence of LW on the retention of allochtonous organic matter, and on the species richness of benthic macro-invertebrates in the Vuelta de Zorra third order stream, in Southern Chile.

\section{STUDY SITE}

The study area corresponds to the a third order 586.8 hectares Vuelta de Zorra catchment $\left(39^{\circ} \mathrm{S} ; 79^{\circ} \mathrm{W}\right)$ located in the Valdivian Coastal Reserve, near the village of Chaihuín, some $40 \mathrm{~km}$ south-west from the city of Valdivia in southern Chile (Iroumé et al. 2010). Seventy five percent of the catchment area is covered with evergreen native forests, $24 \%$ by Eucalyptus spp. plantations and $1 \%$ by natural regeneration of native species, Figure 1.

In the study catchment altitudes range from 10 to $481 \mathrm{~m}$ a.s.l. and mean hillslope is about $30 \%$. To the west and east of the main channel soils have respectively granitic and metamorphic origins (Iroumé et al. 2010). Soil depth increases from the higher altitudes to the flood plains which are formed by alluvial gravels and finer sandy and loamy deposits (Gallo 2009).

Precipitation and discharge are being measured in the study catchment (see gauging locations in Fig. 1) with continuous digital recorders installed in July 2008. The water level gauging station is located in a natural section of the river channel and controls a catchment area of 585.3 ha.

The catchment has a pluvial regime with maximum monthly discharges occurring during the winter rainy months (MayAugust). Between 2009 and 2011 mean minimum and maximum monthly discharges were registered in March and August with 0.17 and $21.63 \mathrm{~m}^{3} \mathrm{~s}^{-1}$, and the driest and wettest months were January and August with 94 and $548 \mathrm{~mm}$, respectively. Long-term mean annual rainfall in the city of Valdivia is $\sim 2300 \mathrm{~mm}$ (Iroumé et al. 2006), although long term rainfall in the study site could be higher as mean annual rainfall for period 2009-2011 was $2172 \mathrm{~mm}$ in Valdivia and $2690 \mathrm{~mm}$ in Vuelta de Zorra.

\section{METHODS}

Since 2008 a $1557 \mathrm{~m}$-long segment of the main stream of the Vuelta de Zorra catchment is been surveyed for LW and channel morphological characterization (Iroumé et al. 2010, 2011; Ulloa et al. 2011). Within this segment six reaches were chosen specially for this research to produce two groups of three reaches each clearly different in terms of stored LW volume. Additionally the high LW volume reaches were selected among those having at least one $\log$-jam. The identification of these reaches is shown in Figure 1b.

Within individual reaches mean channel slope $(S)$ and mean bankfull width and depth were calculated following Iroumé et al. (2010), and predominant bed morphology was defined

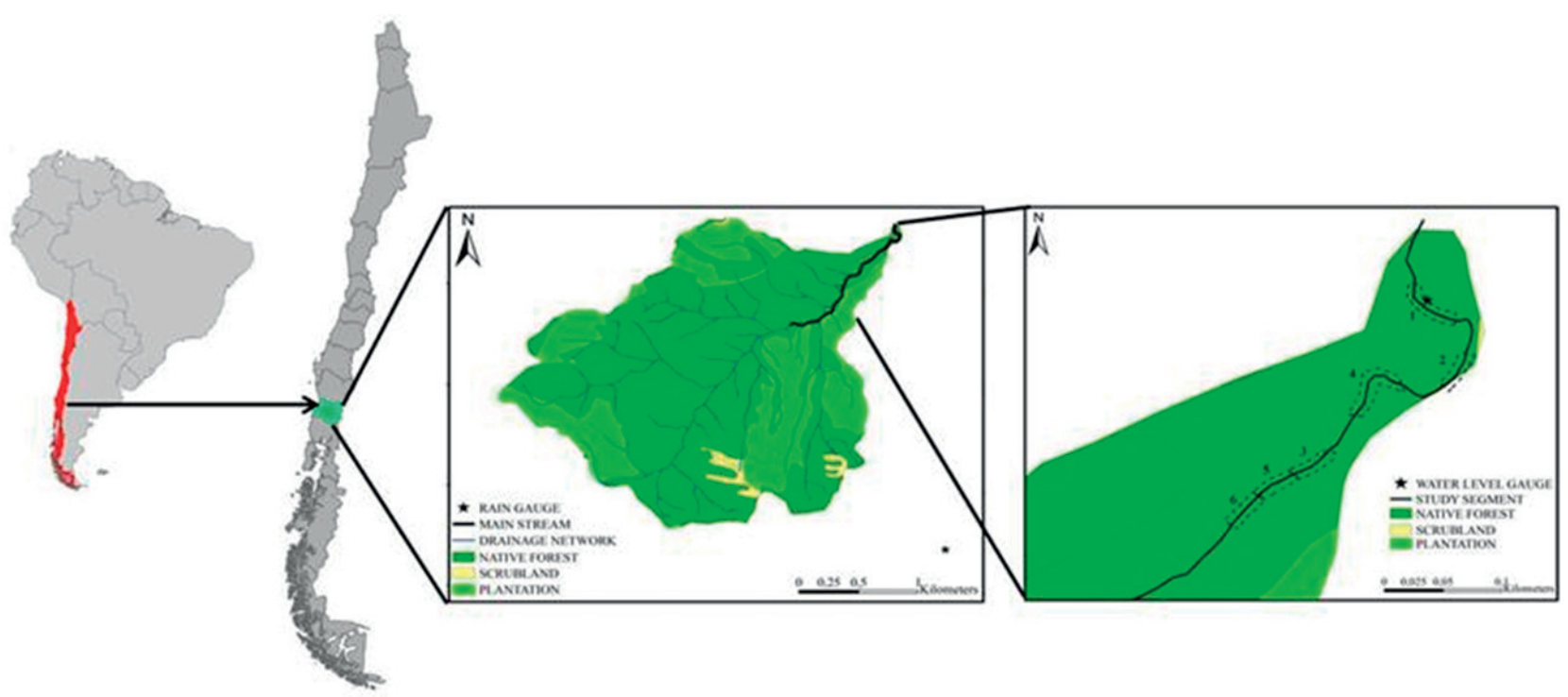

FIGURE 1. Land use (left) and detail of the study reaches (right) Vuelta de Zorra catchment, southern Chile.

Figura 1. Uso del suelo (izquierda) y detalle de los tramos estudiados (derecha), cuenca Vuelta de Zorra, sur de Chile. 
accordingly to Montgomery and Buffington (1997). LW volume was calculated from all wood pieces with dimensions of greater than $10 \mathrm{~cm}$ in diameter and $1 \mathrm{~m}$ in length having part of their length within the bankfull channel. The volume of every single element or jam forming log was calculated from its mid diameter and length assuming a solid cylindrical shape (Andreoli et al. 2007; Iroumé et al. 2010), and LW accumulations were classified after Abbe and Montgomery (2003). The volume of sediment stored behind log steps and jams was estimated assuming a solid wedge, whose streamwise length and upstream and downstream width and height were measured with a tape as in Comiti et al. (2008). Channel characterization was performed in December 2010 after the rainy season.

Individual reach flow resistance was expressed in terms of the Darcy-Weisbach friction factor $\left(f_{D-W}\right)$ using the following expression:

$$
f_{D-W}=\frac{8 g h S}{v^{2}}
$$

with $g$ the gravitational acceleration $\left(9.8 \mathrm{~m} \mathrm{~s}^{-1}\right), h$ the reachaveraged flow depth (m), $S$ the reach slope $\left(\mathrm{m} \mathrm{m}^{-1}\right)$ and $v$ the reach-average velocity $\left(\mathrm{m} \mathrm{s}^{-1}\right)$. Reach-averaged flow depths (h) were used in Equation (1) instead of cross sectional hydraulic radius, as done by Curran \& Wohl (2003). Flow depths at the upstream and downstream ends of each study reach were obtained averaging water level measured in 5-6 vertical profiles to then calculate reach-averaged flow depth. We assumed that the Darcy-Weisbach friction factor represents total flow resistance within each individual reach, i.e. is the addition of grain, form and spill resistances as indicated by Comiti et al. (2009). During field campaigns reach-average flow velocity and discharge were calculated by means of the salt tracer method (Comiti et al. 2008; Curran \& Wohl 2003; MacFarlane \& Wohl 2003) using two portable conductivity meters (WTW Cond 330I with probe Tetracon 325). Reach flow resistance was measured in December 2010 and July and August 2012.

\section{RETENTION OF ORGANIC MATTER}

Retention of coarse particle organic matter (CPOM, organic particles $>1 \mathrm{~mm}$ according to Hauer \& Lamberti 2007; Vannote 1980) was assessed releasing into the channel a known number of particles easily distinguishable and collecting them downstream following Lamberti \& Gregory (2007) and Pozo et al. (2009). In this case, beech (Fagus sylvatica $L$.) leaves were used which were chosen for their distinctive yellow color when collected in autumn and because is a tree species not found in the study area. As indicated by Raikow and Grubbs (1995) and Speaker et al. (1984), the beech leaves were stored in fabric bags and kept in dry and ventilate sites and then rehydrated for 12 hours to obtain neutral buoyancy before performing the field CPOM retention tests following Brookshire and Dwire (2003), Elosegi \& Sabater (2009), Hauer \& Lamberti (1996), Rodríguez et al. (2007) and Speaker et al. (1984). Once rehydrated, 200 leaves were released in the upstream end of each reach and then captured at the downstream end and recorded at one minute intervals.

A preliminary retention test exercise was performed in May 2011 to investigate transport times. Then, two field beech leave retention tests were accomplished in winter 2011 (June and July) and two in spring-summer (November 2011 and January 2012).

\section{BENTHIC MACRO-INVERTEBRATES}

Macro-invertebrate benthic communities in the Vuelta de Zorra stream were sampled on two occasions, in April and June 2011 (Southern Hemisphere autumn and winter seasons, respectively). Two different sampling procedures were used, depending on the bed morphology and the CPOM retentive characteristics of each reach. In the LW-high-volume reaches samples were collected among and under the log jams by burying a PVC cylinder $(10 \mathrm{~cm}$ long, $11 \mathrm{~cm}$ of diameter, 95 $\mathrm{cm}^{2}$ of cross sectional area) closed at one end by a $500 \mu \mathrm{m}$ sieve, in the rich organic matter stream bed upper layers. In the LW-low-volume reaches (flat stony stream bed) a Surber sampler, with a cutting area of $900 \mathrm{~cm}^{2}$ was used. Once the Surber sampler was positioned on the stream bed all pebbles in the sampling area were removed, being the retained CPOM and associated macro-invertebrates washed inside the net. In each of the three LW-high-volume reaches 18 samples were taken with the PVC cylinder (54 samples, in all), and two Surber samples in each of the LW-low-volume reaches (6 samples, in all). This survey procedure was defined to assure comparable conditions among PVC (95 $\left.\mathrm{cm}^{2}\right)$ and Surber $\left(900 \mathrm{~cm}^{2}\right)$ samples as nine PVC sampling units (SU) are equivalent in area to one Surber sampling unit. The collected material was fixed and preserved in 95\% pure alcohol, and subsequently analyzed in the laboratory under a $30 \mathrm{X}$ binocular microscope to determine macroinvertebrates to the lowest possible level using Domínguez \& Fernández (2009). The taxonomic composition of the macro-invertebrate community associated with each type of habitat (CPOM rich material accumulated between and under $\log$ jams and stony substrate) was compared using the Bio-Diversity Pro ${ }^{\circledR}$ software, calculating Bray-Curtis indices.

\section{STATISTICAL ANALYSIS}

An ANOVA test was used to compare the Darcy-Weisbach friction factors between low and high LW volume reaches. Multiple and simple linear regressions were used to examine relationships between $\mathrm{OM}$ retention and macro-invertebrate species richness as dependent variables and reach channel characteristics (LW volume, stored sediment volume, 
discharge, flow velocity and Darcy-Weisbach friction factor) as independent variables.

Statistical analyzes were performed using the software STATGRAPHICS ${ }^{\circledR}$ and the relationships were considered statistically significant if $p \leq 0.05$.

\section{RESULTS}

REACH CHANNEL CHARACTERISTICS

Channel characteristics for each of the six study reaches are summarized in Table 1. Reaches 1 to 3 (mean length $43.2 \mathrm{~m}$; mean bankfull width $8.5 \mathrm{~m}$; mean LW volume per reach length $7.6 \mathrm{~m}^{3} / 100 \mathrm{~m}$ ) are the LW-low-volume reaches while reaches 4 to 6 (mean length $45.6 \mathrm{~m}$; mean bankfull width $9.1 \mathrm{~m}$; mean $\mathrm{LW}$ volume $261.6 \mathrm{~m}^{3} / 100 \mathrm{~m}$ ) are the LW-high-volume reaches. LW-low and high volume reaches are dominated respectively by plane bed and forced pool riffle channel morphologies.

Most of the in-stream wood pieces in reaches 1, 2, 3 and 5 are jam forming logs, Table 2. Reaches 4 and 6 concentrate the higher volume as single elements, with 25.7 and $29.6 \%$ of total LW volume, respectively. Most of the accumulations are transport jams in the low LW volume reaches and combination jams in the high LW volume reaches.

The $95 \%$ of the wood volume in the LW-low-volume reaches are in accumulations and the $78 \%$ of these are Bench-jams. In the LW-high-volume reaches the $81 \%$ of the wood volume are in accumulations, and the $95.2 \%$ of the accumulations are Valley-jams, see Tables 1 and 2.

The volume of sediments stored in LW-high and low volume reaches is significantly different. Mean sediment volume is
15 and $1 \mathrm{~m}^{3} / 100 \mathrm{~m}$ in high and low LW reaches respectively (see Table 1). The Darcy-Weisbach friction factor $\left(f_{D-W}\right)$ varies between 0.10 and 2.33 in LW-low-volume reaches and from 1.53 to 10.51 in LW-high-volume reaches, Table 1. The median for $f_{D-W}$ is 0.96 for the former reaches and 5.18 for the latter ones (see Fig. 2) indicating that friction factor is significantly affected $(p<0.05)$ by the abundance of in-stream LW.

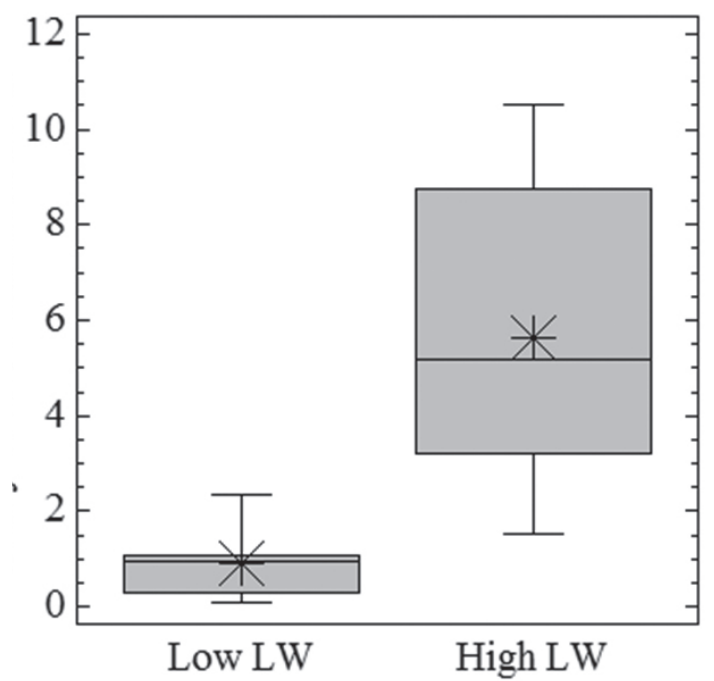

FIGURE 2. Box plots of Darcy-Weisbach friction factor for low and high LW volume reaches. The cross and line within each box indicate the mean and median values, box ends are $25^{\text {th }}$ and $75^{\text {th }}$ percentiles, whiskers are the $10^{\text {th }}$ and $90^{\text {th }}$ percentiles.

Figura 2. Diagrama de caja del factor de fricción de DarcyWeisbach para tramos con bajo y alto volumen de LW. La cruz y la línea en cada caja indican los valores de la media y mediana, los extremos de las cajas los cuartiles 25 y $75 \%$, y los bigotes los valores del 10 y $90 \%$.

TABLE 1. Reach scale channel characteristics.

TABLA 1. Características del canal a escala de tramo.

\begin{tabular}{|c|c|c|c|c|c|c|}
\hline \multirow{2}{*}{$\begin{array}{l}\text { Reach } \\
\text { number }\end{array}$} & Length & $\begin{array}{l}\text { Bankfull } \\
\text { width }\end{array}$ & Slope & \multirow{2}{*}{$\begin{array}{l}\text { Predominant bed channel } \\
\text { morphology }{ }^{1}\end{array}$} & $\begin{array}{l}\text { Volume of } \\
\text { LW }\end{array}$ & $\begin{array}{l}\text { Volume of } \\
\text { sediments }\end{array}$ \\
\hline & (m) & (m) & $(\mathrm{m} / \mathrm{m})$ & & $\left(\mathrm{m}^{3} / 100 \mathrm{~m}\right)$ & $\left(\mathrm{m}^{3} / 100 \mathrm{~m}\right)$ \\
\hline 1 & 53.55 & 8.64 & 0.006909 & Plane Bed & 5.66 & 2.3 \\
\hline 2 & 35.73 & 8.83 & 0.010076 & Plane Bed & 14.97 & 0 \\
\hline 3 & 38.22 & 8.19 & 0.012821 & Plane Bed & 2.90 & 0 \\
\hline 4 & 65.61 & 8.62 & 0.014022 & Forced Pool Riffle & 326.96 & 33.34 \\
\hline 5 & 35.12 & 7.89 & 0.028759 & Forced Pool Riffle & 205.52 & 3.04 \\
\hline 6 & 36.17 & 10.83 & 0.012718 & Forced Pool Riffle & 252.25 & 9.77 \\
\hline
\end{tabular}

${ }^{1}$ According to Montgomery and Buffington (1997). 
TABLE 2. LW volume per reach and accumulation type.

TABLA 2. Volumen de LW por tramo y tipo de acumulación.

\begin{tabular}{|c|c|c|c|c|c|c|}
\hline & \multicolumn{3}{|c|}{ LW volume } & \multicolumn{3}{|c|}{ LW volume in accumulations } \\
\hline & $\left(\mathrm{m}^{3}\right)$ & $\left(\mathrm{m}^{3} / 100 \mathrm{~m}\right)$ & $\left(\mathrm{m}^{3} \mathrm{ha}^{-1}\right)$ & Accumulation type $^{1}$ & $\left(\mathrm{~m}^{3}\right)$ & $\left(\mathrm{m}^{3} / 100 \mathrm{~m}\right)$ \\
\hline \multirow[t]{2}{*}{ Reach 1} & 3.03 & 5.66 & 65.49 & Flow Deflection & 0.85 & 1.59 \\
\hline & & & & Bench Jam & 2.18 & 4.07 \\
\hline \multirow[t]{3}{*}{ Reach 2} & 5.35 & 14.97 & 169.57 & Bench Jam & 4.3 & 12.04 \\
\hline & & & & Bank input & 0.81 & 2.27 \\
\hline & & & & Log step & 0.24 & 0.67 \\
\hline \multirow[t]{2}{*}{ Reach 3} & 1.11 & 2.89 & 35.46 & Bench Jam & 0.74 & 1.94 \\
\hline & & & & Bank input & 0.19 & 0.49 \\
\hline \multirow[t]{5}{*}{ Reach 4} & 214.52 & 326.97 & 3793.07 & Log step & 3.74 & 5.70 \\
\hline & & & & Valley Jam & 152.7 & 232.74 \\
\hline & & & & Bank input & 0.81 & 1.24 \\
\hline & & & & Flow Deflection & 0.2 & 0.31 \\
\hline & & & & Bench Jam & 1.87 & 2.85 \\
\hline \multirow[t]{4}{*}{ Reach 5} & 72.18 & 205.53 & 2604.87 & Log step & 0.56 & 1.60 \\
\hline & & & & Bank input & 4.5 & 12.81 \\
\hline & & & & Valley Jam & 65.45 & 186.36 \\
\hline & & & & Bench Jam & 1.67 & 4.76 \\
\hline \multirow[t]{3}{*}{ Reach 6} & 91.24 & 252.25 & 2329.21 & Valley Jam & 63.4 & 175.28 \\
\hline & & & & Bank input & 0.72 & 1.99 \\
\hline & & & & Bench Jam & 0.12 & 0.33 \\
\hline
\end{tabular}

${ }^{1}$ According to Abbe and Montgomery (2003).

CPOM RETENTION THROUGH LEAVES RETENTION

The retention of leaves ranged from 40 to $90 \%$ in LW-lowvolume reaches (reaches 1, 2 and 3) and between $65-95 \%$ in LW-high-volume reaches (4, 5 and 6), Figure 3. The mean leave retention is 72 and $90 \%$ for the LW-low and high volume reaches respectively, although this difference is not statistical significant.

As shown in figure 4, the arrival patterns are relatively similar but the number of leaves incoming in different periods differs among LW-low and high-volume reaches. The 17.5 and the $3 \%$ of the leaves arrived in the first five minutes in the LW-low and high-volume reaches, respectively. The $70 \%$ of the leaves arrived in the first eight minutes in the LW-low-volume reaches, and in the LW-high-volume reaches this percentage was completed in 16 minutes. These values are similar when comparing the autumn-winter and the spring-summer campaigns.

A significant multiple linear regression $(p$-value $<0.05$,
$R=0.63$ ) relates CPOM retention with $\mathrm{LW}$ volume (LW in $\left.\mathrm{m}^{3} / 100 \mathrm{~m}\right)$, Darcy-Weisbach friction factor $\left(f_{D-W}\right)$ and discharge $\left(\mathrm{Q}\right.$, in $\left.1 \mathrm{~s}^{-1}\right)$. LW volume is the variable showing the higher correlation $(R=0.61)$ with retention, figure 5 .

\section{DIVERSITY OF BENTHIC MACRO-INVERTEBRATE}

Twenty six taxonomic units were collected from the sampling campaign realized in April, and this number increased significantly in June to 41 units. Table 3 summarizes all registered taxonomic units, in some cases identified at the gender level.

In figure 6, the solid and segmented lines represent the richness of the LW-low and LW-high volume reaches, respectively, for the campaign in April. It can be observed that sampling unit 1 (SU1) has a very low percentage of similarity with the four remaining SU (average 20\%), and that the more similar sampling units in the LW-poor reaches are SU3 and SU4 (60\%). 

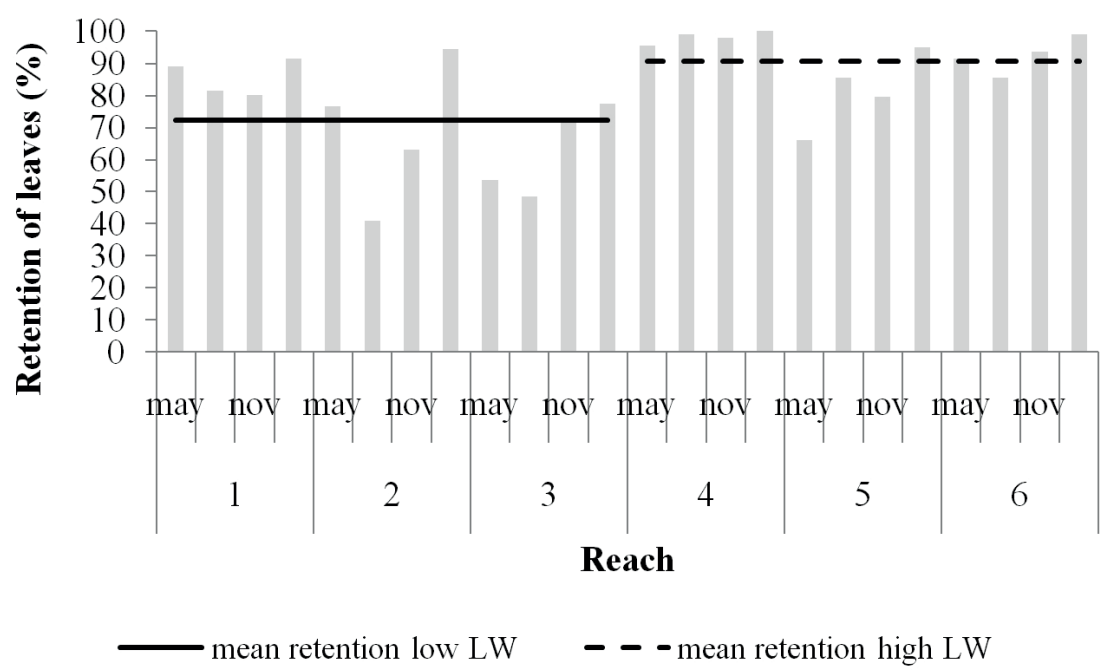

Figure 3. Retention of leaves (\%) per reach and sampling period.

Figura 3. Retención de hojas (\%) por tramo y periodo de muestreo.

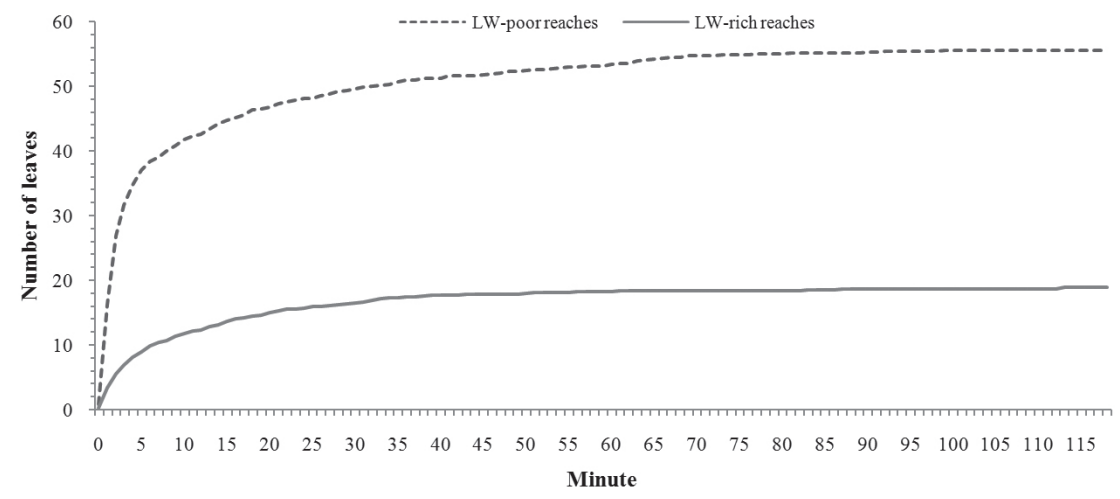

FIGURE 4. Cumulative number of leaves arriving at each time interval in LW-low and LW-high volume reaches.

FIgURA 4. Número acumulado de hojas que llegan en cada intervalo de tiempo en tramos con menor y mayor volumen de LW.

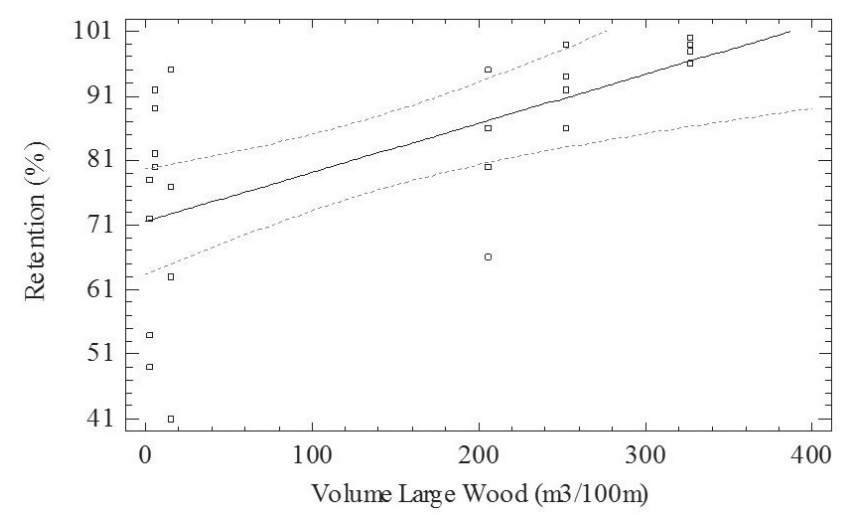

FigURE 5. Relationship between CPOM retention and LW volume.

Figura 5. Relación entre retención de CPOM y volumen de LW. 
TABLE 3. Number of taxonomic units in Vuelta de Zorra.

TABla 3. Número de unidades taxonómicas en Vuelta de Zorra.

\begin{tabular}{|c|c|c|c|c|c|c|}
\hline \multirow[b]{2}{*}{ TAXON } & \multirow[b]{2}{*}{ FAMILY } & \multirow[b]{2}{*}{ GENDER } & \multicolumn{2}{|c|}{ APRIL } & \multicolumn{2}{|c|}{ JUNE } \\
\hline & & & Low-LW & High-LW & Low-LW & High-LW \\
\hline \multirow[t]{3}{*}{ Ephemeroptera } & Leptophlebiidae & Meridialaris & 104 & 201 & 89 & 123 \\
\hline & Coloburiscidae & Murphyella & 0 & 0 & 0 & 2 \\
\hline & Baetidae & & 22 & 2 & 57 & 1 \\
\hline \multirow[t]{17}{*}{ Plecoptera } & Diamphipnoidae & Diamphipnopsis & 0 & 10 & 11 & 188 \\
\hline & Grypopterigidae & Antarctoperla & 0 & 3 & 15 & 31 \\
\hline & Grypopterigidae & Chilenoperla & 0 & 0 & 0 & 9 \\
\hline & Grypopterigidae & Ceratoperla & 0 & 0 & 0 & 1 \\
\hline & Grypopterigidae & Araucanioperla & 0 & 0 & 0 & 10 \\
\hline & Grypopterigidae & Andiperla & 0 & 0 & 0 & 3 \\
\hline & Grypopterigidae & Limnoperla & 0 & 0 & 0 & 2 \\
\hline & Grypopterigidae & Notoperla & 0 & 0 & 0 & 4 \\
\hline & Grypopterigidae & Rithroperla & 0 & 0 & 0 & 5 \\
\hline & Grypopterigidae & Pelurgoperla & 0 & 1 & 0 & 0 \\
\hline & Grypopterigidae & & 18 & 48 & 0 & 0 \\
\hline & Perlidae & Pictetoperla & 1 & 11 & 1 & 3 \\
\hline & Notonemuridae & Udamocercia & 4 & 0 & 2 & 5 \\
\hline & Austroperlidae & Klapopteryx & 19 & 7 & 13 & 40 \\
\hline & Austroperlidae & Penturoperla & 1 & 12 & 0 & 4 \\
\hline & Eustheniidae & Neuroperla & 0 & 0 & 2 & 1 \\
\hline & Ameletopsidae & Chaquihua & 0 & 3 & 0 & 0 \\
\hline \multirow[t]{8}{*}{ Trichoptera } & Odontoceridae & & 1 & 17 & 2 & 14 \\
\hline & Sericostomatidae & & 0 & 0 & 0 & 2 \\
\hline & Helicopsychidae & Helicopsyche & 0 & 0 & 0 & 6 \\
\hline & Leptoceridae & & 0 & 0 & 0 & 2 \\
\hline & Hydropsichidae & Smicridea & 12 & 0 & 16 & 2 \\
\hline & Calamoceratidae & Phylloicus & 7 & 4 & 0 & 2 \\
\hline & Rhyacophylidae & & 2 & 0 & 1 & 0 \\
\hline & Limnephilidae & & 0 & 2 & 0 & 0 \\
\hline \multirow[t]{7}{*}{ Coleoptera } & Elmidae & Indet & 0 & 0 & 0 & 5 \\
\hline & Elmidae & Hexanchorus & 0 & 0 & 0 & 12 \\
\hline & Elmidae & Stegoelmis & 0 & 0 & 0 & 1 \\
\hline & Elmidae & & 15 & 3 & 19 & 0 \\
\hline & Psephenidae & Tychepsephenus & 36 & 10 & 21 & 17 \\
\hline & Psephenidae & Ectopria & 0 & 1 & 30 & 13 \\
\hline & Dytiscidae & & 0 & 0 & 0 & 1 \\
\hline \multirow[t]{7}{*}{ Diptera } & Tipulidae & & 28 & 19 & 39 & 8 \\
\hline & Chironomidae & & 0 & 0 & 0 & 7 \\
\hline & Simuliidae & & 0 & 0 & 8 & 1 \\
\hline & Indet & & 0 & 0 & 1 & 0 \\
\hline & Athericidae & & 2 & 0 & 7 & 0 \\
\hline & Blephariceridae & & 0 & 0 & 1 & 0 \\
\hline & Ceratopogonidae & & 2 & 1 & 0 & 0 \\
\hline Odonata & Aeshnidae & & 0 & 0 & 0 & 1 \\
\hline \multirow[t]{2}{*}{ Crustacea } & Aeglidae & Aegla & 5 & 16 & 4 & 7 \\
\hline & Parastacidae & Samastacus & 0 & 2 & 0 & 0 \\
\hline Arachnida & Acari & Indet & 0 & 0 & 0 & 1 \\
\hline Annelida & Oligochaeta & & 5 & 1 & 5 & 0 \\
\hline \multirow[t]{2}{*}{ Acari } & & & 1 & 0 & 0 & 0 \\
\hline & & & 285 & 374 & 344 & 534 \\
\hline
\end{tabular}


A larger number of samples were collected in June allowing a more complete analysis; SU11 and SU12 have a lower percentage of similarity with the other sampling units, whereas the SU with higher similarities are SU1 and SU2, followed by SU3 and SU4, both with a $75 \%$ of similarity, as illustrated in figure 7 . This dendrogram shows again the difference between LW-low-volume and LW-high-low volume reaches in term of species similarity.

Figure 7.

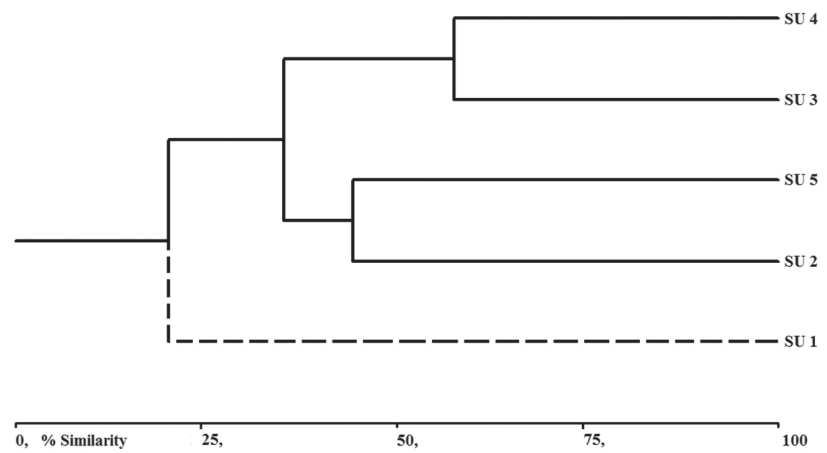

Figure 6. Bray-Curtis dendrogram for richness; April sampling.

Figura 6. Dendrograma de Bray-Curtis; muestro en abril.

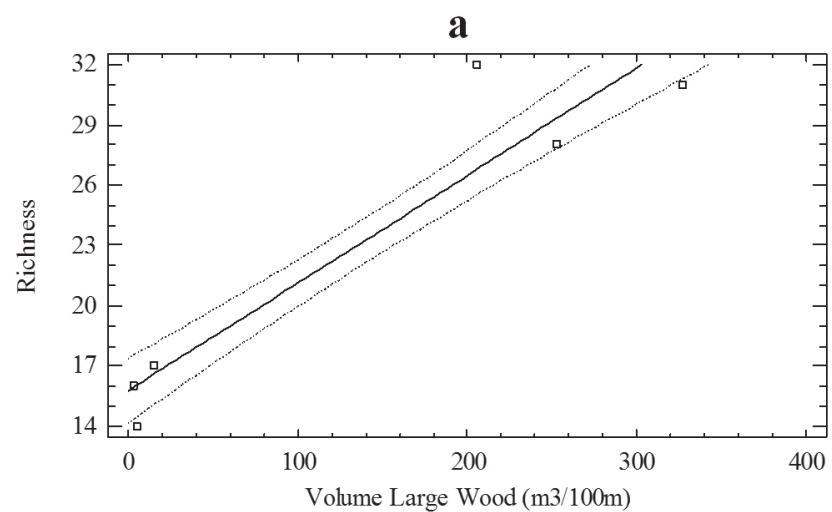

A significant multiple linear regression ( $p$-value $<0.05, R$ $=0.99$ ) was found between species diversity (richness) as dependent variable and leave retention (\%), LW volume $\left(\mathrm{m}^{3} / 100 \mathrm{~m}\right)$, Darcy-Weisbach friction factor $\left(f_{D-W}\right)$ and discharge $\left(\mathrm{Q}\right.$, in $\left.1 \mathrm{~s}^{-1}\right)$ as independent variables. Among these last three variables richness was highly correlated with LW volume $(R=0.94)$ and retention $(R=0.48)$, Figure 8 .

Figure 8 .

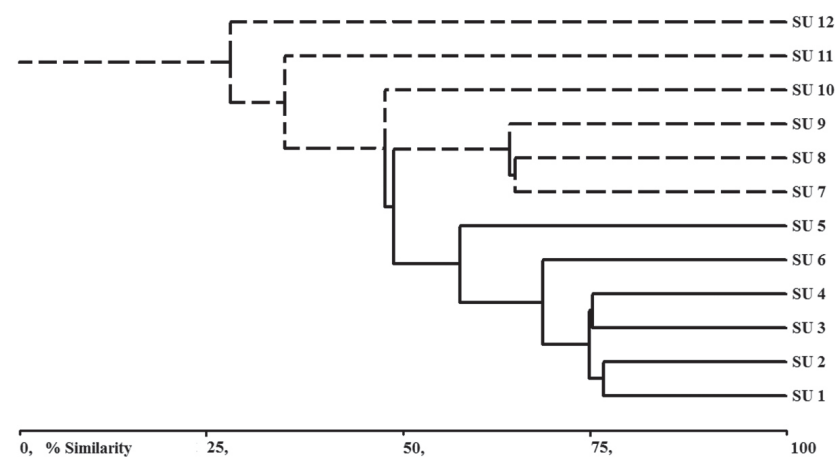

FIgURE 7. Bray-Curtis dendrogram for richness; June sampling.

Figura 7. Dendrograma de Bray-Curtis; muestro en junio.

b

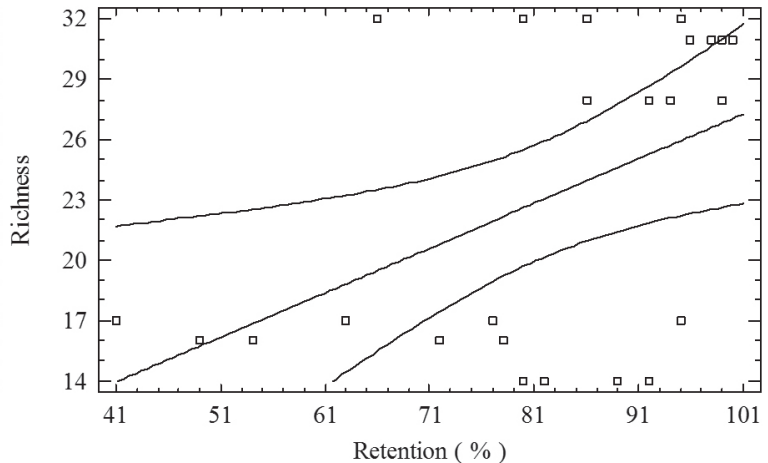

FIGURE 8. Relationships between: a) richness and LW volume, b) richness and leave retention.

FiguRa 8. Relación entre: a) riqueza y volumen de LW, b) riqueza y retención de hojas.

\section{DISCUSSION}

\section{CPOM RETENTION}

In the Vuelta de Zorra stream, retention is mainly influenced by the LW volume, confirming Gerhard \& Reich (2000) and Tank et al. (2010) who indicate that the presence of instream wood generally increases POM retention, increasing the efficiency of the system to process leaf litter into smaller size fractions and the energy sources to the stream, and reducing the organic matter export. Log jams are very important in accumulating organic matter, and Bilby \& Likens (1980) report that debris dams contain nearly $75 \%$ of the standing stock of organic matter in first-order streams, and this percentage reduces to $58 \%$ and $20 \%$ in second and third order streams, respectively. Flores et al. (2011) report that after the incorporation of logs in stream, the CPOM in experimental reaches was 2.4-71.2 times higher than that in controls, suggesting a strong effect of wood addition on the storage of organic matter. 
Although in this Vuelta de Zorra study LW volume greatly influenced retention, there are other stream bed features that play important roles for organic matter retention. For instance, in streams where the substrate is dominated by large particles (boulders, coarse gravel, pebbles and rock) sediments can retain a large proportion of the leaves being transported by the water. Trent et al. (2010) suggest that the retention is linked to the number of retaining structures, assumption that is fulfilled in this work as the average retention in LW-low-volume reaches is $72 \%$ and in the LW-high-volume reaches $90 \%$ values. Another feature that stands out in retention is the stream flow. RodríguezBarrios and Ospina (2007) found a negative trend between flow magnitude and the percentage of retained leaves, with a correlation of $-74 \%(\mathrm{p}<0.01)$. In this situation the LW acts as major obstacle to the transport of organic matter only in periods were flow is at medium level, as in autumn when the OM retention is mostly due to the presence of wood elements (Raikow et al. 1995).

BENTHIC MACRO-INVERTEBRATES: RICHNESS, ABUNDANCE AND BRAY-CURTIS INDEX

From data it is concluded that the difference in species richness between LW-low and high volume reaches is caused by the preference of insects for a biotope that provide refuge and a suitable organic substrate that sustains them during times of otherwise food scarcity. The rising richness observed from April to June, from 26 to 41 species, presumably responds to the larger mass of organic matter accumulated from the autumn to the winter period. Similar results were obtained by Norambuena et al. (2012) in a mountain stream, where they found greater species richness associated to the wood elements with larger volumes than in the streambed, contrasting with the average abundance which was three times higher on the streambed than on LW.

The presence of some taxonomic units that only appeared in April in the LW-high volume reaches, such as Perlugoperla personata, characterized as scraper and potentially as deposit-feeder or collector, Antarctoperla (Plecoptera) and Calamoceratidae (Trichoptera) as scrapers, and Limnephilidae (Trichoptera) as consumer of very soft decaying leaves, seems to indicate that the organic substrate on which they feed at that time of the year was subjected to a long period of micro-organisms activity. In June, in those same reaches, Ephemeroptera and Plecoptera, mainly shredders scrapers of logs and leaves respectively, were quite abundant, Elmidae (Coleoptera), Tipulidae (Diptera) and Chironomidae (Diptera), which are also consumers of soft decaying organic matter, were less abundant, while Odonata as predators appeared with very low abundance. Seemingly, Flores et al. (2011) found that shredders represented 10.2\% of the total invertebrates in 2006 and $26.3 \%$ in 2008, having no statistical difference between control and experimental reaches before and after wood addition; subsequently, after the introduction of wood in all streams shredders tended to increase in density.

As for the abundance species individuals, the following order was detected, from highest to lowest number of individuals per taxa: Ephemeroptera $>$ Plecoptera $>$ Coleoptera $>$ Diptera $>$ Trichoptera. This order according to the number of individuals per taxa, suggests that at the Vuelta de Zorra stream there is a high benthic primary productivity, deduced from the abundance of Leptophlebiid ephemeropterans which mostly function as scrapers. At least, some Leptophlebiid species seems to have a good adaptation for living on logs. Plecoptera and Coleoptera species are mostly shredders, and their abundance is connected with the large number of leaves accumulated under log dams. Tipulid and Simuliid dipterans are associated with leaves in an advanced state of decomposition; Tipulids drill and eat that soft matter while Simuliids filter fine particles derived from the digestion of decaying organic matter by shredders. Finally, Trichoptera mostly feed on soft rotten leaves or on deposits of fine particulate organic material derived from leaves decay. Baillie (2011) observed that total invertebrate densities in debris dams were $70 \%$ higher than in riffles.

Finally, Bray-Curtis similarity dendrogram for April shows a low similarity between LW-low and high volume reaches, and in June the same pattern repeats. In June, sampling units (SU) obtained from LW-low-volume reaches have a similarity above $60 \%$ among them, while the SU obtained from LW-high-volume reaches were less similar, indicating that a high diversity is not uniform across the reaches with high abundance of logs. We suggest that in the LW-highvolume reaches high diversity occurs for two reasons: first, invertebrates normally drift and reach the barriers represented by logs where they attach stochastically, and second, high diversity could be related with the preference of benthic macro-invertebrates for leaves and logs accumulations, chosen as biotopes. Both reasons seem to explain the high diversity and differences between high and low LW-volume reaches.

\section{RiCHNESS, RETENTION AND LW}

Richness is higher in heterogeneous environments, composed by several different substrates, high patchiness and large perimeters. Those mosaics offer many potential niches for invertebrates; on the opposite, a very homogeneous environment offers a low variety of niches and refuge for few taxa (Biesel et al. 2000; Negishi \& Richardson 2003; Gerhard \& Reich 2000). The same effects were detected in this Vuelta de Zorra study, where greater species richness associated to LW volumes, and therefore, a greater availability of niches, were found. 
Norambuena et al. (2012) observed that LW has a positive effect on the benthic invertebrate community structure, affecting parameters such as taxonomic richness, abundance, diversity, and proportion of functional groups among the taxonomic units found at the study site; besides the retained OM. That is why the addition of logs into the channel, as a restoration technique, increases the availability of food for insect larvae and nymphs, thereby helping to increase their abundance (Entrekin 2008). Many studies aimed to the restoration of banks and streambeds have verified the positive influence of LW in the lotic systems. Thus, a study conducted in coastal plain streams in south-eastern U.S., typically dominated by shifting sands substrate, corroborated the importance of LW as a substrate for macro-invertebrates. Increasing with stream order, dams are productive substrate for invertebrate colonizers because they provide stable substrate (relative to sand), refuge from current, and substrate for growth of invertebrate forage (Drury \& Kelso 2000). Additionally, in headwater areas, detritus associated with allocthonous LW input serves as food for collector and shredder invertebrate species, whereas in autochthonous downstream areas, woody debris is more important as substrate for collector and predator species (Vannote et al. 1980).

Hrodey et al. (2007) observed that subsequent to the installation of wood in a stream channel, half-logs were colonized and showed statistically significant increases in both relative abundance and richness of macro-invertebrates over time. That result indicates that the extent of colonization and use of logs was largely dependent upon the pre-existing in-stream habitat quality and the predominant land-use type. Restoration studies, involving wood reintroduction, have been carried out in forested landscapes, but some results might be extrapolated to agricultural streams. In those studies it was demonstrated that the addition of wood enhanced diversity of fish and macro-invertebrates, increased storage of organic material and sediment, and improved bed and bank stability (Lester \& Boulton, 2008).

The results of this study has contributed to improve the understanding of the role of LW in the ecohydrology of a Chilean river localized in the Coastal mountain range, an area where more than the $70 \%$ of the original forest cover has been lots in the last centuries (Bello et al. 2003).

\section{CONCLUSIONS}

Mean CPOM retention was $72 \%$ in low LW volume reaches and $90 \%$ in high LW volume reaches, but the difference is not statistically significant. CPOM retention is positively related with $\mathrm{LW}$ volume $\left(\mathrm{m}^{3} 100 \mathrm{~m}^{-1}\right)$.
Benthic macro-invertebrate richness is positively related with LW volume $\left(\mathrm{m}^{3} 100 \mathrm{~m}^{-1}\right)$ and CPOM retention (in \%). High LW volume reaches have twice the number of species and abundance than low LW volume reaches. Species richness is higher in LW-rich reaches compared to LW-poor reaches. Furthermore, there is no significant similarity as the sampling units do not share a large number of taxonomic units. There is a high diversity in LW-high volume reaches, because macro-invertebrates prefer logs as a biotope that offers refuge and food.

Our results can guide environmental impact assessments of projects affecting natural rivers and also stream restoration projects, where the incorporation of LW would increase availability of CPOM, sediment retention, invertebrate richness and ichthyofauna enrichment, so to enhance the ecosystem services in riverine environments.

\section{ACKNOWLEDGEMENTS}

This research was undertaken within the framework of Project Fondecyt 1110609. We also acknowledge the valuable comments and suggestions by two anonymous reviewers.

\section{BIBLIOGRAPHY}

Abbe, T.B. \& Montgomery, D.R. 2003. Patterns and processes of wood debris accumulation in the Queets river basin, Washington. Geomorphology 51: 81-107.

Andreoli, A., Iroumé, A., Carlig, G. \& Comiti F. 2007. Residuos leñosos de gran tamaño en un torrente de la Cordillera de Los Andes, Chile: su funcionalidad e importancia. Bosque 28(2): 83-96.

Baillie, B. 2011. The physical and biological function of wood in New Zealand's forested stream ecosystems. PhD Thesis in Biological Sciences. University of Waikato. 155 p.

Bello, M., Tecklin, D. \& Farias, A. 2003. Fundamentos técnicos para el establecimiento de un área silvestre protegida en el fundo fiscal Quitaluto, Cordillera Pelada, X Región de los Lagos. WWF Chile.

Biesel, J.N., Usseglio-Polatera, P. \& Moreteau, J.C. 2000. The spatial heterogeneity of a river bottom: a key factor determining macro-invertebrates communities. Hydrobiologia 422/423: 163-171.

Bilby, R. \& Likens, G. 1980. Importance of organic debris dams in the structure and function of stream ecosystems. Ecology 61(5): 1107-1113

BILBY, R. \& WARD, J. 1989. Changes in characteristics and function of woody debris with increasing size of streams in western Washington. Transactions American Fisheries Society 118: 368-378.

Bilby, R. \& Bisson, P. 1998. Function and distribution of Large Wood Debris. In: River ecology and management: Lessons from the Pacific Coastal Ecoregion.Naiman (Eds. R. \& 
Bilby, R.), pp. 324 - 347. Springer, New York.

Brookshire, J. \& Dwire, K. 2003. Controls on patterns of coarse organic particle retention on headwater streams. The North American Benthological Society 22 (1): 17-34.

Castro, M. \& Melo, A. 2008. An experimental test of the effects of inorganic sediment addition on benthic macroinvertebrates of a subtropical stream. Hydrobiologia 610: 321-329.

Comiti, F., Mao, L., Wilcox, A., Wohl, E. \& Lenzi, M. 2007. Field-derived relationships for flow velocity and highgradient streams. Hydrology 340: 48-62.

Comiti, F., Andreoli, A., Lenzi, M. \& Mao, L. 2008. Wood storage in three mountain streams of the Southern Andes and its hydro-morphological effects. Earth Surface Processes and Landforms 33(2): 244-262.

Comiti, F., CAdol, D. \& Wohl, E. 2009. Flow regimes, bed morphology, and flow resistance in self-formed steppool channels. Water Resources Research 45: W04424, doi:10.1029/2008WR007259

Curran, J. \& Wohl, E. 2003. Large woody debris and flow resistance in step-pool channels, Cascade Range, Washington. Geomorphology 51(1-3): 141-157.

Death, R., Baillie, B. \& Fransen, P. 2003. Effect of Pinus radiata logging on stream invertebrate communities in Hawke's Bay, New Zealand. New Zealand Journal of Marine and Freshwater Research 37: 507-520.

Domínguez, E. \& Fernández, H. 2009. Macro-invertebrados bentónicos sudamericanos. Sistemática y Biología. Tucumán, Argentina. Fundación Miguel Lillo. 654 p.

DruRY, D. \& Kelso, W. 2000. Invertebrate colonization of woody debris in coastal plain streams. Hydrobiologia 434: 63-72

Elosegui, A. \& Sabater, S. 2009. Conceptos y técnicas en ecología fluvial. España. Fundación BBVA. 424 pp.

Entrekin, S.A. 2008. The response of organic matter dynamics and macroinvertebrates to experimental wood additions in 3 Michigan streams. PhD Thesis. Notre Dame, Indiana. Program in Biological Sciences, University of Notre Dame. 276 p.

Flores, L., Larrañaga, A., Díez, J. \& Elosegi, A. 2011. Experimental wood addition in streams: effects on organic matter storage and breakdown. Freshwater Ecology 56: 2156-2167.

Gallo, C. 2009. Estudio de la movilidad y reclutamiento de material leñoso en la cuenca del estero Vuelta de la Zorra, Chaihuín, Cordillera de la Costa, sur de Chile. Facultad de Ciencias Forestales y Recursos Naturales, Universidad Austral de Chile. 42 p.

Gerhard, M. \& Reich, M. 2000. Restoration of Streams with Large Wood: Effects of Accumulated and Built-in Wood on Channel Morphology, Habitat Diversity and Aquatic Fauna. International Review of Hydrobiology 85: 123137.

Gregory, S., Swanson, F., Mckee, W.A. \& Cummins, K. 1991. An ecosystem perspective of riparian zones. BioScience 41(8): 540-551.

Gurnell, A.M. \& Sweet, R. 1998. The distribution of large woody debris accumulations and pools in relation to woodland stream management in a small, low gradient stream. Earth Surface Processes and Landforms 23: 1101-1121.

Hauer, F.R. \& Lamberti, G.A. 2007. Methods in stream ecology.
Estados Unidos. Elsevier. 877 p.

Hrodey, P., Kalb, B. \& Trent, S. 2007. Macro-invertebrate community response to large-woody debris additions in small warmwater streams. Hydrobiologia 605: 193-207.

Iroumé, A., Mayen, O. \& Huber, A. 2006. Runoff and peak flow responses to timber harvest and forest age in Southern Chile. Hydrological Processes 20(1): 37-50.

Iroumé, A., Andreoli, A., Comiti, F., UlloA, H. \& Huber, A. 2010. Large wood abundance, distribution and mobilization in a third order coastal mountain range river system, southern Chile. Forest Ecology and Management 260: 480-490.

Iroumé, A., Ulloa, H., Lenzi, M., Andreoli, A. \& Gallo, C. 2011. In-stream large wood mobility and recruitment in two channels in the Coastal Mountain Range, Chile. Bosque 32(3): 247-254.

Keller, E. \& Swanson, F. 1979. Effects of large organic material on channel form and fluvial processes. Earth Surface Processes and Landforms 4(4): 361-380.

LAmberti, G.A. \& Gregory, S.V. 2007. CPOM transport, retention, and measurement. In Hauer F.R., Lamberti G.A. Methods in stream ecology. Estados Unidos. Elsevier. pp. 273-289.

Larrañaga, S., Díez, J.R., Elosegui, A. \& Pozo, J. 2003. Leaf retention in streams of the Aguera basin (northern Spain). Aquatic Sciences 65: 158-166.

Lester, R. \& Boulton, A. 2008. Rehabilitating Agricultural Streams in Australia with Wood: A Review. Environmental Management 42: 310-326.

MacFarlane, W. \& Wohl, E. 2003. Influence of step composition on step geometry and flow resistance in step-pool streams of the Washington Cascades. Water Resources Research 39(2): doi: 10.1029/2001WR001238. Montgomery DR, Buffington JM. 1997. Channel-reach morphology in mountain drainage basins. Geological Society of America Bulletin 109: 596-611.

MuotKa, T. \& LAASONEN, P. 2002. Ecosystem recovery in restored headwater streams: the role of enhanced leaf retention. Applied Ecology 39: 145-156.

Negishi, J. \& Richardson, J. 2003. Responses of organic matter and macro-invertebrates to placements of boulder clusters in a small stream of southwestern British Columbia, Canada. Canadian Journal of Fisheries and Aquatic Sciences 60: 247-258.

Norambuena, J., Palma, R., Encina, F. \& Iroumé, A. 2012. Grandes detritos leñosos (LWD) y su relación con ensambles de macro-invertebrados bentónicos en un río de Pre-cordillera Andina, Chile. "Sistemas acuáticos en el límite: amenazas, oportunidades y conocimiento". IX Congreso de la Sociedad Chilena de Limnología, 112.

Pozo, J., Elosegui, A., Díez, J. \& Molinero, J. 2009. Dinámica y relevancia de la materia orgánica. In: Conceptos y técnicas en ecología fluvial (Eds. Elosegui, A. \& Sabater, S.), pp. 140-167. Fundación BBVA. España.

Raikow, D., Grubbs, S. \& Cummins, K. 1995. Debris dam dynamics and coarse particulate organic matter retention in an Appalachian Mountain stream. The North American Benthological Society 4(4): 535-546.

Rodríguez, J. \& Ospina, R. 2007. Retención de materia orgánica particulada gruesa en una quebrada de montaña tropical, Bogotá, Colombia. Acta Biológica Colombiana 12(1): 33-46. 
Speaker, R., Moore, K. \& Gregory, S. 1984. Analysis of the processes ofretention of organicmatterinstreamecosystems. Verhandlungen des Internationalen Verein Limnologie 22: $1835-1841$

Stepenuck, K., Crunkilton, R., Bozek, M. \& Wang, L. 2008. Comparison of macroinvertebrate-derived stream quality metrics between snag and riffle habitats. Journal of the American Water Resources Association 44(3): 670-678.

Swanson, F.J. \& Lienkaemper, G.W. 1984. Interactions among fluvial processes, forest vegetation, and aquatic ecosystems, South Fork Hoh River, Olympic National Park. In: Proc. 2nd Conference on Scientific Research in the National Parks (Eds. Starkey, E.E., Franklin, J.F. \& Matthews, J.W.), p. 30-34. Oregon State Univ., Corvallis, OR.

Tank, J., Rosi-Marshall, E., Griffiths, N., Entrekin, S. \& Stephen, M. 2010. A review of allochthonous organic matter dynamics and metabolism in streams. North American Benthological Society 29(1): 118-146.

Trent, H., MarczaK, L., Richardson, J. \& Yonemitsu, N. 2010. Transport and settlement of organic matter in small streams. Freshwater Biology 55: 436 - 449.

Ulloa, H., Iroumé, A., Lenzi, M., Andreoli, A., Alvarez, C. \& BARRERA, V. 2011. Large wood in two catchments from the Coastal Mountain range with different land use history. Bosque 32(3): $247-254$.

Vannote, R., Minshall, G., Cummnins, K., Sedel, J. \& Cushing, C. 1980. The river continuum concept. Canadian Journal of Fisheries and Aquatic Sciences 37: $130-137$.

Webster, J., Covich, A., TAnK, J. \& Crockett, T. 1994. Retention of coarse organic particles in streams in the southern Appalachian Mountains. The North American Benthological Society 13(2): $140-150$.

Recibido: 17.03 .14

Aceptado: 24.09.14 